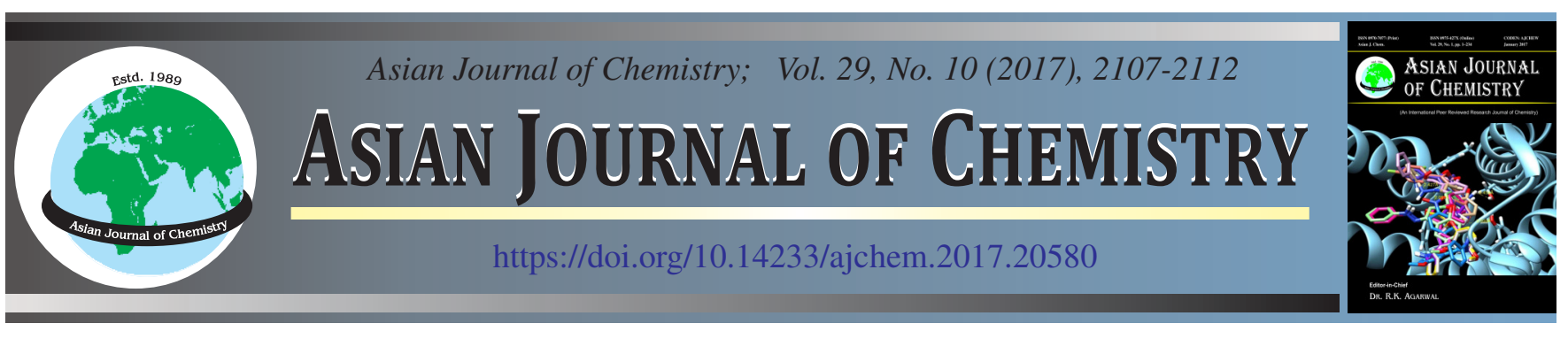

\title{
Four Factor Surface Response Optimization of Ethyl Palmitate from Terminalia cattapa L. Kernel Oil
}

Erin Ryantin Gunawan ${ }^{1, *}$, Dedy Suhendra ${ }^{1}$, Arista Dewi Nurita $^{1}$ and Dessy Komalasari ${ }^{2}$

${ }^{1}$ Department of Chemistry, Faculty Mathematics and Science, University of Mataram, Mataram, Indonesia

${ }^{2}$ Department of Mathematics, Faculty Mathematics and Science, University of Mataram, Mataram, Indonesia

*Corresponding author: E-mail: erinryantin@unram.ac.id

Received: 13 February 2017;

Accepted: 19 May 2017;

Published online: 31 August 2017;

AJC-18500

\begin{abstract}
Optimization of ethyl palmitate through enzymatic reaction with lipozyme of Terminalia cattapa L. kernel oil and ethanol was carried out. Response surface methodology (RSM) based on a five-level four-factor central composite rotatable design (CCRD) was used to evaluate the interactive effects of synthesis, of reaction time $(3-7 \mathrm{~h})$, temperature $\left(35-55^{\circ} \mathrm{C}\right)$, amount of enzyme $(0.1-0.3 \mathrm{~g})$ and substrate molar ratio (kernel oil to ethanol, 1:1-1:3) on the percentage yield of ethyl palmitate The optimum conditions obtained in the amount of enzyme $0,19 \mathrm{~g}$, molar ratio of ketapang seed oil:ethanol of $1: 2,5(\mathrm{~g} / \mathrm{g})$, a reaction time of $4.68 \mathrm{~h}$ and a temperature of $44.82{ }^{\circ} \mathrm{C}$ with a predicted yield of $40.031 \%$. The model recommended to obtain optimal results is a quadratric model with R-squared value of 0.7955 .
\end{abstract}

Keywords: Ethyl palmitate, Terminalia cattapa L. Kernel oil, Four factor surface, Response surface methodology, Lipozyme.

\section{INTRODUCTION}

Ethyl palmitate is the ester derivatives of palmitic acid which is a saturated fatty acid. Chemical formula of this compound is $\mathrm{C}_{18} \mathrm{H}_{36} \mathrm{O}_{2}$. It is a colorless solid with a wax-like odor. Esters are important organic compounds with increasing number of commercial applications [1]. Ethyl palmitate are infrequent found in the nature, except the base material synthesized from saturated fatty acids, such as palmitic acid.

Palmitic acid contained in palm oil (39.2-45.8\%) [2], corn oil 8.0-12.0\%, soybean oil 7-10\%, canola oil 3.0-7.0\%, 4.1-17.3\%, sun flower, 2.0-6.0 \%, linseed 4.0-7.0\% [3], coconut 4.6-20.0\% [4]. Transesterification reaction of oils which contained palmitic acid and ethanol will produce ethyl palmitate. Ethyl palmitate can be used as a raw material in the manufacture of cosmetics, detergents, additives at the textile and paper [5], flavors and pharmaceuticals and hydraulic fluids [6]. Ethyl palmitate is used as a hair and skin-conditioning agent as well.

Ethyl palmitate in commercial applications has been hampered due to the low amounts that can be recovered from natural sources $[7,8]$. Therefore, most of the available esters are produced by chemical or enzymatic synthesis. Chemical transesterification method leads to high energy consumption and degradation of ester produced. Meanwhile, The biotechnological production of ethyl palmitate using lipases has received particular attention due to the mild reaction conditions involved, the high degree of purity achieved, and the acceptance of these products in food industry [7].

Natural sources of palmitic acid derived from edible oil. Therefore, as an alternative to other fruit kernel oil is used as basic materials such as Terminalia cattapa L. Kernel Oil or ketapang kernel oil (local language). Terminalia cattapa $L$. tree is fruitful for three times a year and this tree does not bear fruit by the season. Therefore, the availability of fruits are abundant and available throughout the year [9]. Previous research showed that the yield of crude oil from the Terminalia cattapa $L$. is $50.40-58.4 \%$. Fatty acid content of the Terminalia cattapa $L$ kernel oil is palmitic acid (25-30\%), oleic acid (35$55 \%)$, linoleic acid (12-16\%) and stearic acid (4-7\%) [10]. These show that economically, Terminalia cattapa L. kernel oil can be extracted and converted into ethyl ester or ethyl palmitate, especially.

In the previous studies, the ethyl ester has been synthesized from Terminalia cattapa $L$ kernel oil through enzymatic reaction using immobilized lipase [10]. The classical method of optimization involves varying one parameter at a time and keeping the other constant. Unfortunately, the method is inefficient as it fails to understand the relationships between the variables and the response (percentage yield). Therefore, we need the other methods that able to observe more than two variables, simultaneously. The most appropriate method is a factorial central composite rotatable design-response surface methodology (RSM-CCRD). The main advantage of CCRD- 
$\mathrm{RSM}$ is the reduced number of experiments, faster and less expensive method [11]. This method gives the optimum conditions which can be applied to the production of ethyl palmitate in industrial scale (scale-up reaction) and able to evaluate the interactive effects.

\section{EXPERIMENTAL}

Terminalia cattapa L. kernel oil and lipozime TL.IM were procured from Novo Nordisk (Denmark). Ethanol, ethyl linoleate standards and $n$-hexane were obtained from Sigma Aldrich (USA). Other chemicals were of analytical grade.

Statistical design: A four-factor-five-level CCRD was employed in this research, requiring 30 experiments. The factorial design consisted of 6 centre points, 16 factorial points and 8 axial points. The variables and their levels selected for the ethyl palmitate synthesis were: reaction time (3-7 h), substrate molar ratio (kernel oil to ethanol, 1:1-1:3) amount of enzyme (0.1-0.3 g) and temperature $\left(35-55^{\circ} \mathrm{C}\right)$.

Synthesis and analysis: The mixture of kernel oil, ethanol and lipozyme TL IM were incubated in a horizontal water bath shaker at $150 \mathrm{rpm}$. Reaction time, temperature, amount of enzyme and molar ratio followed by the predictions of 30 data obtained previously by Design Expert software v.7. Each sample was incubated in a water bath shaker at a speed of 150 rpm during the period and a specific temperature. The reaction product was analyzed by using GC-MS using the parameters/ optimum condition as it has been developed by Suhendra et al. [11].
Data analysis: The data from the experiments performed are analyzed using design expert software v.7 [12]. Four main analytical steps: analysis of variance (ANOVA), a regression analysis, the plotting of RSM and the countour were performed to establish an optimum condition for the transesterification of kernel oil.

\section{RESULTS AND DISCUSSION}

Experimental design: Experimental data for transesterification of kernel oil and ethanol are given in Table-1. Experiments were conducted using a central composite design that helps in investigating models (linear, two factorial, quadratic or cubic). The variables studied were reaction time, molar ratio, amount of enzyme and temperature.

The assay conditions for reaction parameter were taken at one level (+1 and -1$)$ and zero level (center point). The experimental design was extended up to \pm the axial point of 2 . The center values for variables were based on previous studies and were carried out at least three times for the estimation of error. The results of the transesterification reaction is analyzed using GCMS instrument to observe peak that have an equal retention time with the standard and the area produced. Data chromatogram of each trial (actual percentage yield) inputted into the Software Design Expert v.7, to obtain the predicted yield as given in the Table-1.

Model fitting and ANOVA: Fitting of the data to various models and their succeeding ANOVA indicated that the reaction

\begin{tabular}{|c|c|c|c|c|c|c|}
\hline \multirow[b]{2}{*}{ S. No. } & \multicolumn{5}{|c|}{$\begin{array}{l}\text { TABLE-1 } \\
\text { CENTRAL COMPOSITE ROTATABLE DESIGN FOR 4-FACTOR-5-LEVEL FROM } \\
\text { RESPONSE SURFACE ANALYSIS OF TRANSESTERIFICATION OF KETAPANG SEED OIL }\end{array}$} & \multirow[b]{2}{*}{$\begin{array}{l}\text { Predicted } \\
\text { yield }(\%)\end{array}$} \\
\hline & $\begin{array}{l}\text { Reaction } \\
\text { time }(\mathrm{h})\end{array}$ & $\begin{array}{l}\text { Molar ratio } \\
\text { (ethanol) (g) }\end{array}$ & $\begin{array}{l}\text { Amount of } \\
\text { enzyme }(\mathrm{g})\end{array}$ & $\begin{array}{c}\text { Temperature } \\
\left({ }^{\circ} \mathrm{C}\right)\end{array}$ & $\begin{array}{c}\text { Actual } \\
\text { yield }(\%)\end{array}$ & \\
\hline 1 & 4 & 2.5 & 0.15 & 50 & 32.28 & 30.92 \\
\hline 2 & 5 & 2.0 & 0.20 & 45 & 37.09 & 36.18 \\
\hline 3 & 4 & 1.5 & 0.25 & 40 & 26.03 & 20.73 \\
\hline 5 & 7 & 2.0 & 0.20 & 45 & 23.52 & 20.21 \\
\hline 6 & 6 & 1.5 & 0.15 & 40 & 21.23 & 23.88 \\
\hline 7 & 5 & 2.0 & 0.20 & 45 & 28.06 & 36.18 \\
\hline 8 & 4 & 1.5 & 0.25 & 50 & 15.38 & 17.51 \\
\hline 9 & 5 & 2.0 & 0.30 & 45 & 22.95 & 21.21 \\
\hline 10 & 6 & 2.5 & 0.25 & 40 & 22.56 & 21.18 \\
\hline 11 & 5 & 1.0 & 0.20 & 45 & 16.61 & 18.14 \\
\hline 13 & 6 & 1.5 & 0.15 & 50 & 29.26 & 25.01 \\
\hline 14 & 6 & 2.5 & 0.25 & 50 & 28.66 & 31.71 \\
\hline 15 & 4 & 1.5 & 0.15 & 50 & 20.87 & 21.15 \\
\hline 16 & 5 & 2.0 & 0.20 & 35 & 25.85 & 23.70 \\
\hline 17 & 5 & 2.0 & 0.10 & 45 & 32.75 & 33.11 \\
\hline 18 & 6 & 1.5 & 0.25 & 50 & 17.92 & 17.46 \\
\hline 19 & 6 & 2.5 & 0.15 & 40 & 29.10 & 29.45 \\
\hline 20 & 6 & 1.5 & 0.25 & 40 & 6.33 & 10.17 \\
\hline 21 & 6 & 2.5 & 0.15 & 50 & 29.60 & 33.81 \\
\hline 22 & 5 & 3.0 & 0.20 & 45 & 41.83 & 38.92 \\
\hline 23 & 5 & 2.0 & 0.20 & 55 & 24.07 & 24.84 \\
\hline 24 & 4 & 2.5 & 0.15 & 40 & 37.69 & 37.06 \\
\hline 25 & 5 & 2.0 & 0.20 & 45 & 32.60 & 36.18 \\
\hline 26 & 4 & 2.5 & 0.25 & 40 & 25.97 & 32.70 \\
\hline 27 & 5 & 2.0 & 0.20 & 45 & 35.80 & 36.18 \\
\hline 28 & 5 & 2.0 & 0.20 & 45 & 34.97 & 36.18 \\
\hline
\end{tabular}


of kernel oil and ethanol were most compatible describe with the quadratic polynomial model. The statistical equation, especially the quadratic polynomial, of kernel oil alcoholysis, given by design expert, is as follows:

$$
\begin{aligned}
\text { Yield }(\%)= & 36.18-1.92 \mathrm{~A}+15.9 \mathrm{~B}-2.98 \mathrm{C}+0.29 \mathrm{D}- \\
& 0.24 \mathrm{AB}-0.98 \mathrm{AC}+2.62 \mathrm{AD}+1.36 \mathrm{BC}+ \\
& 0.81 \mathrm{BD}+1.54 \mathrm{CD}-3.03 \mathrm{~A}^{2}-1.91 \mathrm{~B}^{2}+ \\
& -2.62 \mathrm{C}^{2}-2.98 \mathrm{D}^{2}
\end{aligned}
$$

where $\mathrm{A}$ is the reaction time, $\mathrm{B}$ is the molar ratio, $\mathrm{C}$ is the amount of enzyme and D is the temperature. The effect of reaction time and amount of enzyme are give a negative interactions of the percentage yield. On the other hand, a positive influence is shown by the variable of molar ratio and temperature.

Data ANOVA for joint test are shown in Table-2. On the table, it can be seen that the quadratic models have provided a significant value. The model are significant at $5 \%$ confidence level with $\mathrm{p}$-value of 0.0047 . It also indicated statistically insignificant lack of fit ( $\mathrm{p}$-value of 0,8851 ). Hemanandh and Narayanan [13] reported satisfactory quadratic response models were obtained for Meta Modeling of Emission Parameters of Refined Corn Methy Esters In 4s Diesel Engine.

The value of pure error of the model is sufficiently low, so this indicates that the data obtained has a good reproducible. Meanwhile, a coefficient of determination $\left(R^{2}\right)$ value of 0.7955 (Table-3) showed equation to be not too highly reliable. However, this value is still above the 0.75 values generally considered to be sufficient for adequately representing [11].

\begin{tabular}{cc}
\multicolumn{2}{c}{ TABLE-3 } \\
R-SQUARE VALUE \\
\hline Statistics & Value \\
\hline Standard deviation & 5.37 \\
Mean & 28.04 \\
R-Square & 0.7955 \\
\hline
\end{tabular}

Lower values of $\mathrm{R}^{2}$ has been reported by Osario et al. [14] for novozyme catalyzed transesterification of palm oil stearin with soybean oil $\left(\mathrm{R}^{2}=0.566\right)$ as well as by Kiran et al. $[15,16]$ for lipase-catalyzed synthesis of steoryl and palmitoyl lactic ester $\left(\mathrm{R}^{2}\right.$ 0.565-0.720).

Determination of optimum condition: Following the statistical tests performed, the software Design expert is able give some large selection conditions by the equation of order 2 with a predicted yield for each condition. All the optimum conditions can be used to produce more than $40 \%$ of ethyl palmitate.

The optimum conditions can be seen from the highest yield percent. The optimum condition observed is the amount of enzyme of $0.19 \mathrm{~g}$, reaction time of $4.68 \mathrm{~h}$, molar ratio of 1:2.5 (oil:ethanol, w/w) and temperature of $44.82{ }^{\circ} \mathrm{C}$.

Interactions of variables: Table- 2 shows the variable such as molar ratio and amount of enzyme are the most significant in the process, meanwhile, time and temperature are less significant and not significant effect, respectively on this reaction. The test is also able to investigate the influence or interaction among variables as will be explained below:

\begin{tabular}{cccccc}
\multicolumn{7}{c}{ TABLE-4 } \\
\hline $\begin{array}{c}\text { Experiment } \\
\text { number }\end{array}$ & $\begin{array}{c}\text { Time } \\
(\mathrm{h})\end{array}$ & $\begin{array}{c}\text { Molar ratio } \\
(\mathrm{mmol})\end{array}$ & $\begin{array}{c}\text { Amount of } \\
\text { enzyme }(\mathrm{g})\end{array}$ & $\begin{array}{c}\text { Temp. } \\
\left({ }^{\circ} \mathrm{C}\right)\end{array}$ & $\begin{array}{c}\text { Yield } \\
(\%)\end{array}$ \\
\hline 1 & 4.88 & 2.5 & 0.19 & 44.87 & 40.032 \\
2 & 4.67 & 2.5 & 0.19 & 44.77 & 40.031 \\
3 & 4.69 & 2.5 & 0.18 & 44.77 & 40.030 \\
4 & 4.69 & 2.5 & 0.19 & 44.78 & 40.029 \\
5 & 4.68 & 2.5 & 0.18 & 44.93 & 40.026 \\
\hline
\end{tabular}

Fig. 1 depicts the contour and response surface plot of interactions of reactions time and molar ratio (kernel oil: ethanol). The percentage of yields increased along with the increase of reaction time ( 4 to $4.68 \mathrm{~h}$ ) and thereafter decreased further up to $6 \mathrm{~h}$ (negative effects). Fan et al. [17] reported that too low alcohol/oil molar ratio also led to an incomplete

\begin{tabular}{|c|c|c|c|c|c|}
\hline \multicolumn{6}{|c|}{$\begin{array}{c}\text { TABLE-2 } \\
\text { ANOVA FOR JOINT TEST }\end{array}$} \\
\hline Source & Sum of squares & Degree of freedom & Mean square & F-Value & p-Value $($ prob $>F)$ \\
\hline Model & 1681.33 & 14 & 120.10 & 4.17 & $0.0047^{\mathrm{a}}$ \\
\hline Time (A) & 88.17 & 1 & 88.17 & 3.06 & $0.1007^{\mathrm{b}}$ \\
\hline Molar ratio (B) & 647.50 & 1 & 647.50 & 22.47 & $0.0003^{\mathrm{a}}$ \\
\hline Amount of enzyme (C) & 212.42 & 1 & 212.42 & 7.37 & $0.0160^{\mathrm{a}}$ \\
\hline Temperature (D) & 1.97 & 1 & 1.97 & 0.068 & $0.7972^{\mathrm{b}}$ \\
\hline $\mathrm{AB}$ & 0.93 & 1 & 0.93 & 0.032 & 0.8591 \\
\hline $\mathrm{AC}$ & 15.29 & 1 & 15.29 & 0.53 & 0.4776 \\
\hline $\mathrm{AD}$ & 110.25 & 1 & 110.25 & 3.83 & 0.0693 \\
\hline $\mathrm{BC}$ & 29.70 & 1 & 29.70 & 1.03 & 0.3261 \\
\hline BD & 10.50 & 1 & 10.50 & 0.36 & 0.5551 \\
\hline CD & 38.01 & 1 & 38.01 & 1.32 & 0.2687 \\
\hline A2 & 252.51 & 1 & 252.51 & 8.76 & 0.0097 \\
\hline B2 & 100.37 & 1 & 100.37 & 3.48 & 0.0817 \\
\hline $\mathrm{C} 2$ & 139.53 & 1 & 139.53 & 4.84 & 0.0439 \\
\hline D2 & 243.24 & 1 & 243.24 & 8.44 & 0.1090 \\
\hline Residual & 432.21 & 15 & 28.81 & & \\
\hline Lack of Fit & 197.76 & 10 & 19.78 & 0.42 & $0.8851^{\mathrm{b}}$ \\
\hline Pure error & 234.45 & 5 & 46.89 & & \\
\hline
\end{tabular}
reaction. The contour plots and RSM demonstrated that the optimal conditions for molar ratio and time reactions were about 1:2.5 for kernel oil:ethanol and $4.68 \mathrm{~h}$, respectively, with 

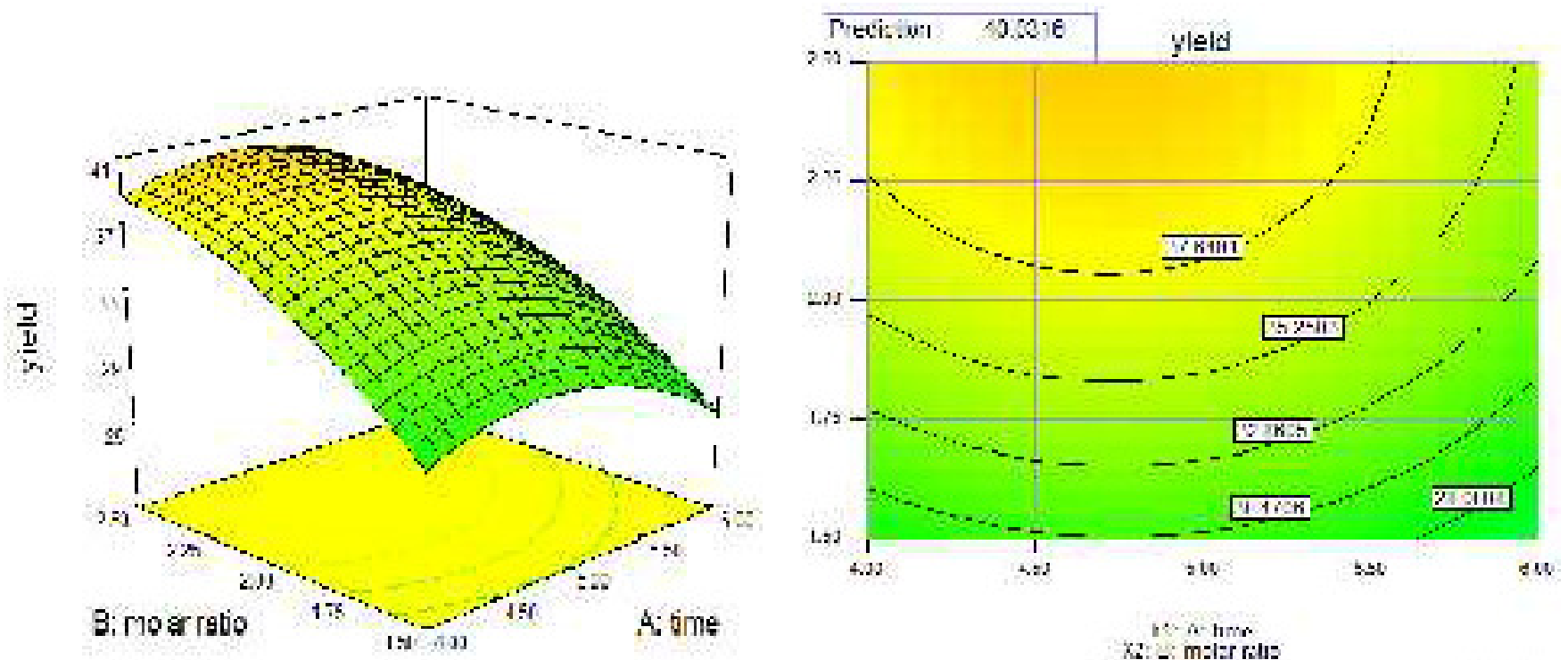

Fig. 1. Contour and response surface plot of interactions of reactions time and molar ratio

percentage of yields is $40.03 \%$. Similar trends for interaction of molar ratio and reaction time was reported by Sukjit and Punsuvon [18] in process optimization of crude palm oil biodiesel.

Fig. 2 represents the effect of varying amount of enzyme and reaction time on alcoholysis reaction. Increasing amount of enzyme and reaction time will lead to an increased percentage of yield until 2.5 of molar ratio and $4.68 \mathrm{~h}$ for reaction time. After that, the percentage of yield will decrease. This may be due to the longer periods of incubation up to $5 \mathrm{~h}$ have clearly brought out the differential behavior of probable unfolding of the enzyme [19].

The effect of varying temperature and reaction time at a constant molar ratio and amount of enzyme is shown in Fig. 3. The interactions between temperature and reaction time of kernel oil alcoholysis are positive effects. The percentage yield increases with increased the incubation time $(4.00$ to $4.50 \mathrm{~h}$ and optimum at $4.68 \mathrm{~h}$ ) but decrease if the temperature was above $44.82{ }^{\circ} \mathrm{C}$. However, the high temperature in the enzymatic reaction caused denaturation of enzyme, thus the decrease in reaction rate occurred [19]. Habulin et al. [20] proposed that lipozyme at $50{ }^{\circ} \mathrm{C}$ existed in equilibrium between inactive and active forms. The alcoholysis reaction of ketapang seed oil was carried out at temperatures ranging from 40 to $50{ }^{\circ} \mathrm{C}$ for 4 to $6 \mathrm{~h}$.

As shown in eqn. 1 and Fig. 4, the effect of the interactions between molar ratio and amount of enzyme of kernel oil alcoholysis are positive effects. Increasing molar ratio will lead to increase of percentage yields of ethyl palmitate. Percentage yields decrease slightly at high amount of lipozyme and substrate molar ratio 1: 2.5 referred maximal percentage yields.

Manohar et al. [21] reported that around critical molar ratio, the competing alcohol binding reduces the formation of the acyl enzyme complex and thereby result in decrease in alcoholysis. The presence of larger amount of substrates generally increases the probability of substrate enzyme collision. Yan et al. [22] investigated that if no mass transfer limitation is present, then the relation between percentage of yields and enzyme concentration should be linear. Due to the nature of the highly concentrated and mainly solid reaction mixtures, it is obvious that effective mixing of reactants and the enzyme is important to provide good transport and contact of the
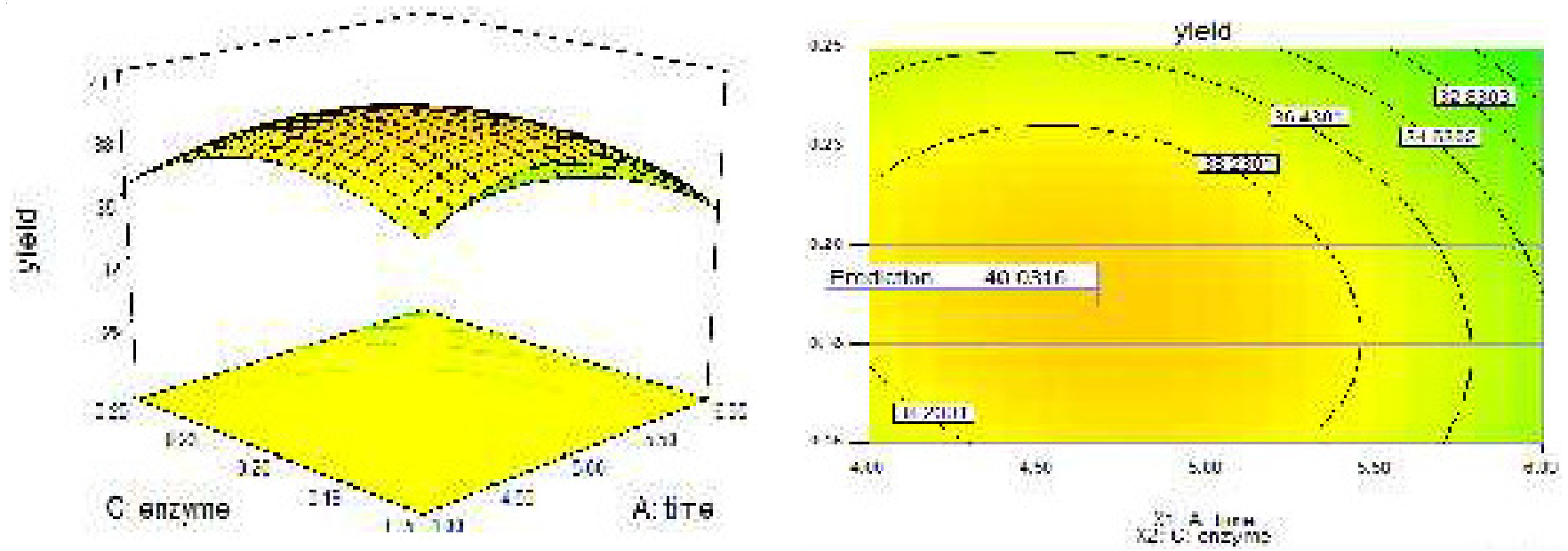

Fig. 2. Countour and response surface plot of interactions of reactions time and amount of enzyme 

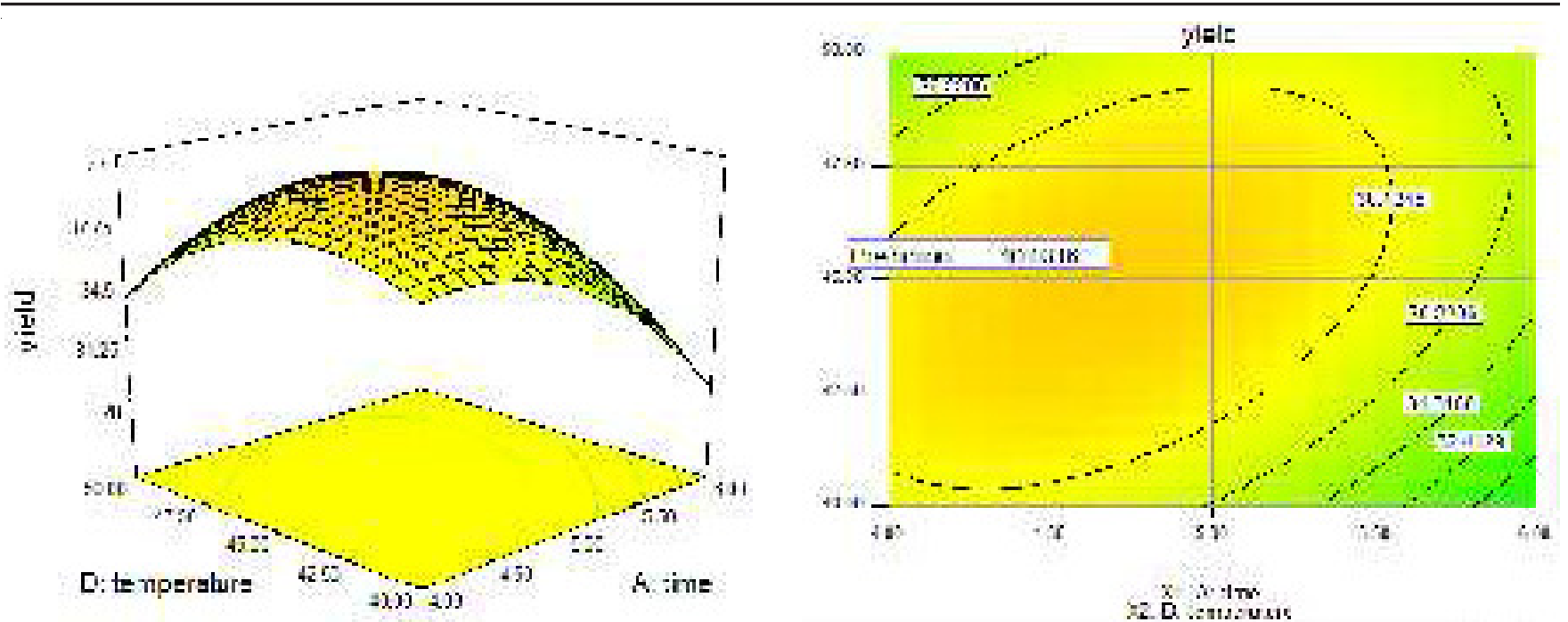

Fig. 3. Countour and response surface plot of interactions of reaction time and temperature
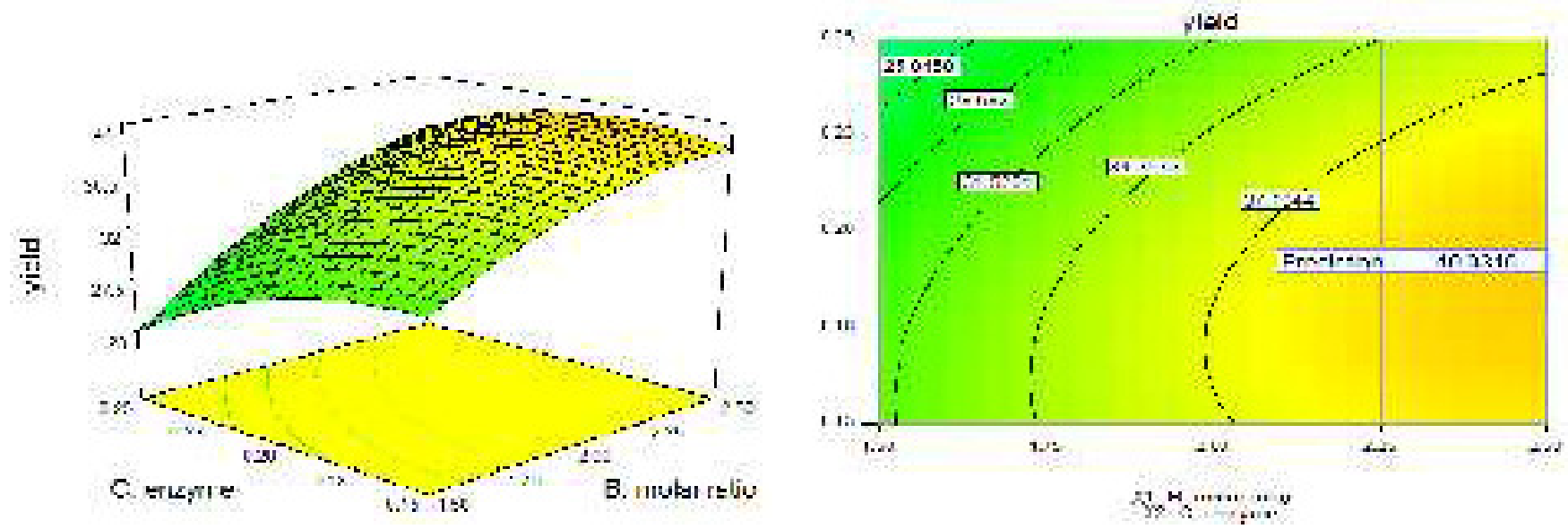

Fig. 4. Countour and response surface plot of interactions of molar ratio and amountof enzyme

reaction partners. The optimum enzyme concentration highly depends on the stirring status.

Fig. 5 represents the effect of varying temperature and substrate molar ratio on kernel oil. Thus, increasing molar ratio will lead to increase of percentage yields and slight decrease at high temperature. Two researchers reported that high temperature has reduced the operational stability [23,24].

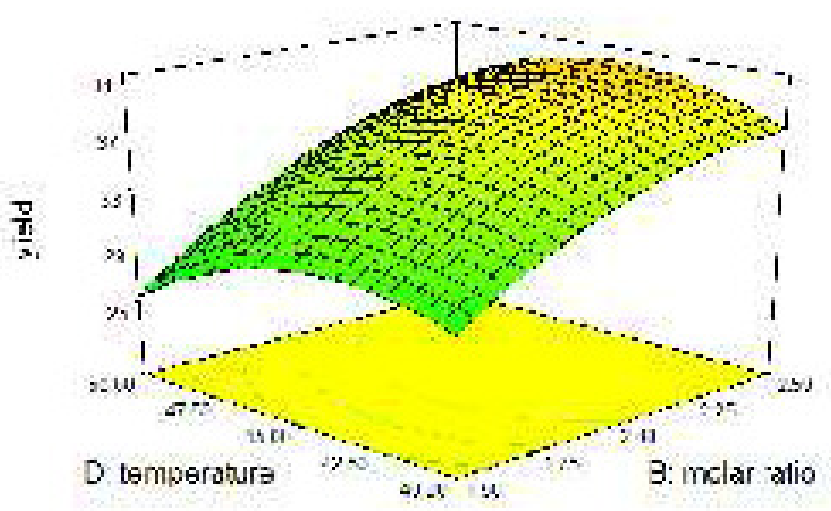

The effect of varying temperature and amount of enzyme is presented in Fig. 6. In this plot, while in one axis there is a linear increase in reaction, other axis showed the increment up to the limit, which decreases thereafter. The typical plot from varying temperature is called dome shaped. This indicates that a critical temperature is involved up to which alcoholysis is favored and it is not so after that critical temperature. Some researches reported that the increase in percentage yield is a

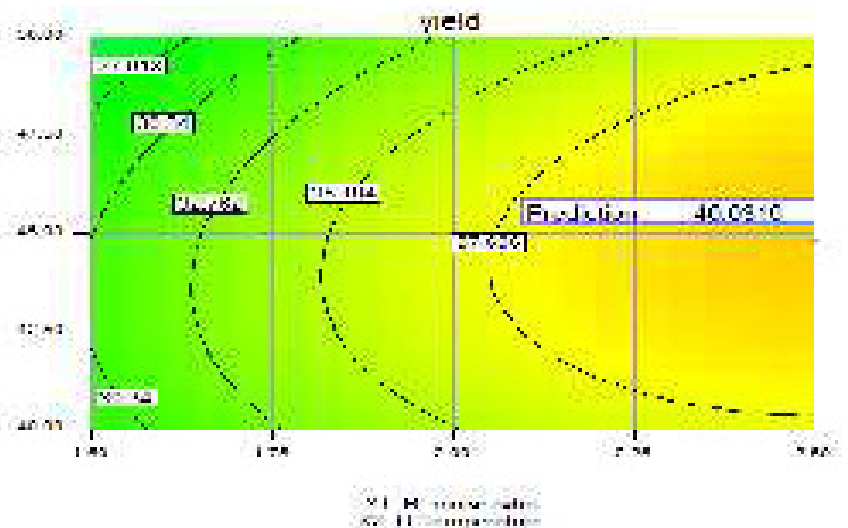

Fig. 5. Countour and response surface plot of interactions of molar ratio and temperature 

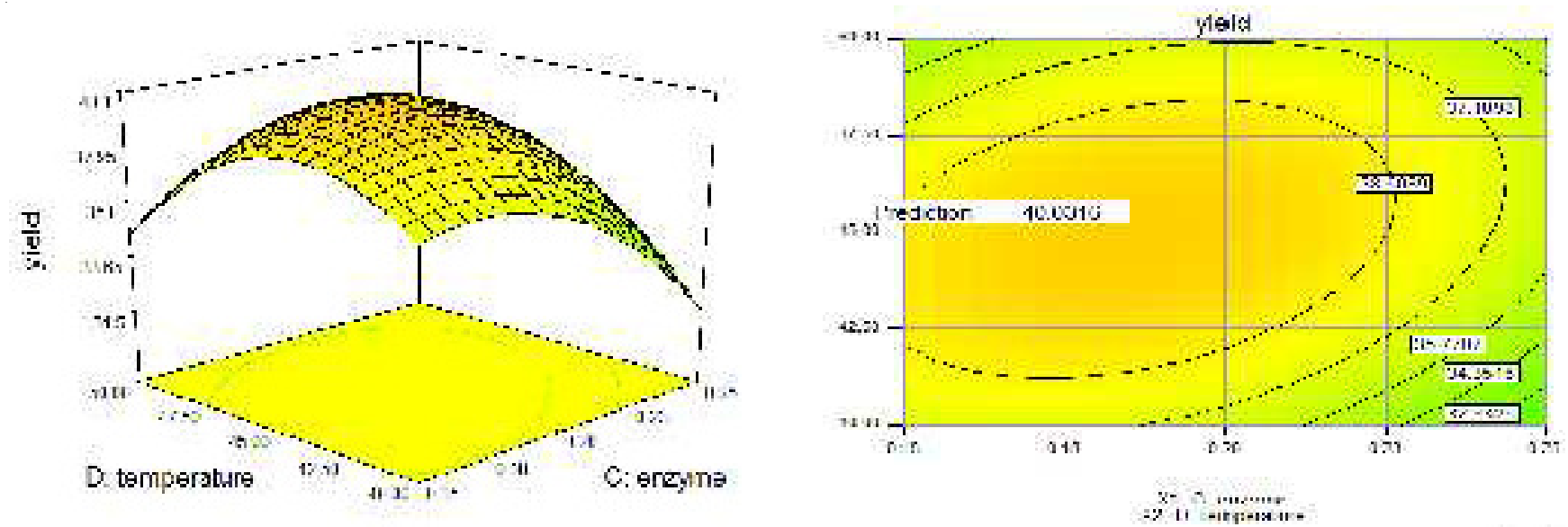

Fig. 6. Countour and response surface plot of interactions of amount of enzyme and temperature

clear indication of the conformational change indicating greater unfolding of the enzyme at $50{ }^{\circ} \mathrm{C}[25,26]$.

\section{Conclusion}

The statistical experimental designs combined with a fivelevel and four factor CCRD has been applied to optimize the synthesis process of ethyl palmitate. The optimum condition values were determined by response surface methodology. The determination coefficient was 0.7955 , which ensure an adequate credibility of the model. The statistical analysis showed that the optimum reaction conditions led to the maximum conversion $(40.03 \%)$ and it has been succesfully evaluate the interactive effects for the enzymatic synthesis of ethyl palmitate from Terminalia cattapa $L$. kernel oil.

\section{ACKNOWLEDGEMENTS}

This project was financed by a grant from Directorate General of Research and Development Strengthening, The Ministry of Research Technology and Higher Education Republic of Indonesia (Agreement Number: 43.Z/SPP-HIKOM/20152016).

\section{REFERENCES}

1. M.L. Foresti, A. Errazu and M.L. Ferreira, Biochem. Eng. J., 25, 69 (2005); https://doi.org/10.1016/j.bej.2005.04.002

2. E. Fattore and R. Fanelli, Int. J. Food Sci. Nutri., 64, 648 (2013); https://doi.org/10.3109/09637486.2013.768213.

3. V. Kostik, S. Memeti and B. Bauer, J. Hyg. Eng. Des., 4, 112 (2013).

4. J. Orsavova, L. Misurcova, J.V. Ambrozova, R. Vicha and J. Mlcek, Int. J. Mol. Sci., 16, 12871 (2015); https://doi.org/10.3390/ijms160612871

5. T. Kimmel, Approved Dissertation, Kinetic Investigation of the BaseCatalyzed Glycerolysis of Fatty Acid Methyl Esters, The Technical University of Berlin, Berlin, Germany (2004).

6. S. Hazarika, N. Goswami, N. Dutta and A. Hazarika, Chem. Eng. J., 85, 61 (2002); https://doi.org/10.1016/S1385-8947(01)00144-9.

7. A. Martínez-Ruiz, H.S. García, G. Saucedo-Castañeda and E. FavelaTorres, Org. Appl. Biochem. Biotechnol., 151, 393 (2008); $\underline{\text { https://doi.org/10.1007/s12010-008-8207-2 }}$
8. L.A.J. Thomson and B. Evans, in ed.: C.R. Elevitch, Terminalia catappa (Tropical Almond), ver. 2.2, Species Profiles for Pacific Island Agroforestry, Permanent Agriculture Resources (PAR), Holualoa, Hawaii, USA (2006).

9. D. Suhendra, R.S.Andriyany, E.R. Gunawan and S.S. Handayani, Proceeding of International Seminar on Economic, Culture and Enviroment, The University of Mataram, Mataram, Indonesia (2010).

10. E.R. Gunawan and D. Suhendra, Indo. J. Chem., 8, 83 (2008).

11. D. Suhendra, E.R. Gunawan, A.D. Nurita, D. Komalasari and T. Ardianto, J. Oleo Sci., 66, 209 (2017); https://doi.org/10.5650/jos.ess 16167.

12. Design Expert version 7.0.4. User's Guide, Section 12, Star-Ease Inc. USA.

13. J. Hemanandh and K.V Narayanan, Int. J. Chemtech Res., 8, 569 (2015).

14. N.M. Osório, S. Ferreira-Dias, J.H. Gusmão and M.M.R. da Fonseca, J. Mol. Catal. B, Enzym., 11, 677 (2001); https://doi.org/10.1016/S1381-1177(00)00156-9.

15. K.R. Kiran, B. Manohar, N.G. Karanth and S. Divakar, Eur. Food Res. Technol., 211, 130 (2000); https://doi.org/10.1007/s002179900123.

16. K.R. Kiran, B. Manohar and S. Divakar, Enzyme Microb. Technol., 29, $122(2001)$ https://doi.org/10.1016/S0141-0229(01)00356-8.

17. X. Fan, X. Wang and F. Chen, The Open Fuels Energy Sci. J., 4, 1 (2011); https://doi.org/10.2174/1876973X01104010001.

18. T. Sukjit and V. Punsuvon, Eur. Int. J. Sci. Technol., 2, 50 (2013).

19. T.T.B. Lan and P.N. Hoa, Biol. Chem. Res., 258 (2015).

20. M. Habulin, V. Krmelj, Z. Knez and J. Agr, Food Chem., 44, 338 (1996); https://doi.org/10.1021/jf950163k.

21. B. Manohar and S. Divakar, Process Biochem., 39, 847 (2004); https://doi.org/10.1016/S0032-9592(03)00192-4.

22. Y. Yan, Institut für Technische Biochemie der Universität Stuttgart (2001).

23. S. Hari Krishna, B. Manohar, S. Divakar, S.G. Prapulla and N.G. Karanth, Enzyme Microb. Technol., 26, 131 (2000); https://doi.org/10.1016/S0141-0229(99)00149-0.

24. N. Bouzaouit and C. Bidjou-Haiour, Der Pharma Chem., 7, 261 (2015).

25. E.R. Gunawan, M. Basri, M.B.A. Rahman, A.B. Salleh and R.N.Z.A. Rahman, Enz. Microb. Technol. J., 37, 739 (2005); https://doi.org/10.1016/j.enzmictec.2005.04.010.

26. S.M. Radzi, M.A. Rosli, H.M. Noor and M.M. Rehan, Procceding of International Conference on Chemical, Environmental and Biological Sciences (ICEBS), Dubai (2015). 